\title{
Isolation of Mycoplasma spp. from Geese with Pneumonia and Identification of Microbial Isolates via Molecular Methods
}

\section{-Author(s)}

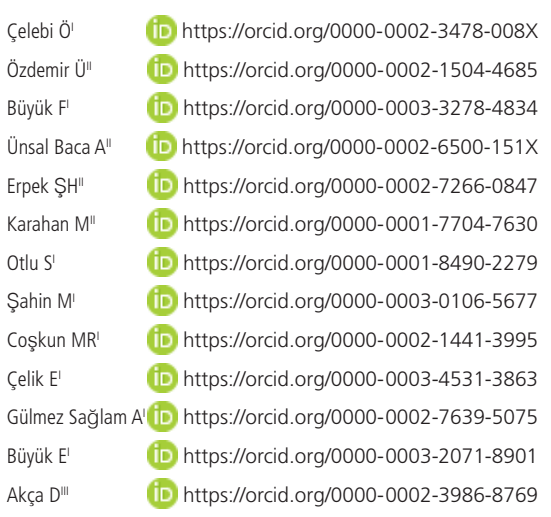

Department of Microbiology Faculty of Veterinary Medicine Kafkas University, Kars, 36100, Turkey.

Republic of Turkey Ministry of Agriculture and Forestry, Pendik Veterinary Control Institute, Istanbul, 34890, Turkey.

III Department of Midwifery Faculty of Health Sciences Kafkas University, Kars, 36100, Turkey.

\section{Mail Address}

Corresponding author e-mail address Özgür Çelebi

Department of Microbiology Faculty of Veterinary Medicine Kafkas University, Kars, 36100, Turkey.

Phone: +90474 2426836

Email: ozgurcelebi36@hotmail.com

\section{-Keywords}

Culture, goose, Mycoplasma spp., PCR, 165 rRNA sequencing.

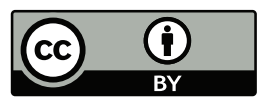

Submitted: 24/May/2021

Approved: 29/September/2021

\section{ABSTRACT}

This study aimed to investigate Mycoplasma species in the lungs of 500 geese with pneumonia from the Kars region (Turkey) via cultural and molecular methods. The samples were cultured on Frey's Broth and Agar media. To identify Mycoplasma species a Growth Inhibition Test was used. The identification was continued with species-specific PCR and sequence analysis which provide amplification of the genes $d n a X, p c r A$, $r p o B$, and the sequence of the 16S rRNA gene, respectively. In addition, Mycoplasma gallisepticum and Mycoplasma synoviae from pneumonic lung samples were directly analyzed via Multiplex Real-time PCR. As a result, 51 Mycoplasma strains were isolated and 32 were identified as Mycoplasma anatis, 9 as Mycoplasma anseris, 5 as Mycoplasma cloacale and 3 as Mycoplasma anserisalpingitis. Two Mycoplasma isolates that could not be identified were grouped in the same branch as a result of 16S RNA sequencing and their nearest neighbour was found to be Mycoplasma sp. 2045 (GenBankNo.MK615061.1). M. gallisepticum DNA was detected in 3 pneumonic lung samples and $M$. gallisepticum/M. synoviae DNAs were found simultaneously in 1 sample. While some Mycoplasma species identified in this study consolidated their place as pneumonic agents, some increased their potential to become a pneumonic agent when compared with cases caused by well-recognized Mycoplasma strains. Two isolates were identified as -Mycoplasma spp. as their 16S rRNA gene sequence identity levels scored below the threshold of $98.7 \%$ for species demarcation and still need to be defined whether they are possible representatives of a novel Mycoplasma species.

\section{INTRODUCTION}

Mycoplasma species have been defined as the microorganisms that lead to several clinical infections, primarily reproductive system infections, peritonitis, airsacculitis, pneumonia and sudden death in poultry. Mycoplasma gallisepticum and Mycoplasma synoviae are responsible for respiratory system infections, arthritis and embryonal deaths in chicken and turkeys, the latter of which results from the widespread in ovo transmission property of the bacteria. In waterfowls such as geese and ducks, Mycoplasma anatis, Mycoplasma anseris, Mycoplasma cloacale and Mycoplasma anserisalpingitis (formerly called Mycoplasma sp. 1220) are common pathogenic Mycoplasma species (Stipkovits \& Szathmary, 2012; Otlu, 2016; Grózner et al., 2019b; Gyuranecz et al., 2020). These Mycoplasma species, together with other infectious microorganisms and environmental factors, play an important role in the immune system of geese. They cause certain pathological lesions and clinical symptoms due to differences in their pathogenesis (FAO, 2002). Respiratory system infections caused by Mycoplasma species progress with nasal discharge, wheezing, coughing and have a moderate mortality rate (5-9\%) in geese 
Celebi Ö, Özdemir Ü, Büyük F, Û̉nsal Baca A, Erpek ŞH, Karahan M, Otlu S, Şahin M, Coşkun MR, Çelik E, Gülmez Sağlam A, Büyük E, Akça D
Isolation of Mycoplasma spp. from Geese with Pneumonia and Identification of Microbial Isolates via Molecular Methods of 1-2 weeks of age, while arthritis is added to these symptoms at 3-4 weeks of age and mortality increases partially. In adult geese, a regression of respiratory system infections is observed with access to fresh air. Infertility, embryonal deaths, cloaca and phallus infections join to respiratory system infections that reemerged during the laying period. In geese of almost all ages, these clinical symptoms are accompanied by pathological lesions such as pneumonia, tracheitis, air sac inflammation, peritonitis and salpingitis (Otlu, 2016).

While $M$. anseris causes classic respiratory tract infections observed in geese, $M$. anatis also causes neurological disorders. $M$. cloacale leads to infertility and causes a decrease in egg production. $M$. anserisalpingitis was first detected in the early 1980s from the inflammation of the cloaca and phallus, and its prevalence gradually increased in the following years (Stipkovits et al., 1986; 1987). Such reproductive diseases caused by $M$. anserisalpingitis leads to significant economic losses in geese breeding (Stipkovits \& Szathmary, 2012). Reports on Mycoplasma sp. 2045 are very limited (Spergser, 2008), and the clinical significance of the microorganism in poultry infections is not yet fully known. Mycoplasma species may cause co-infections in poultry as well as coexist with different viruses and bacteria and negatively affect the course and prognosis of the disease (Tiong, 1990; Stipkovits \& Szathmary, 2012; Samy \& Naguib, 2018). Mycoplasma species can also be found in the normal microbiota of healthy waterfowl such as ducks and geese. Diseases caused by these microorganisms may occur due to stress factors such as insufficient housing conditions and feding, crowded breeding, or an intense laying period (Stipkovits \& Kempf, 1996; de Sá et al., 2015).

The definitive diagnosis of Mycoplasmosis and the identification of the constitutive microorganism at the species or variant level provide valuable data into illuminating the epidemiology of the disease, taking appropriate protection and control measures and assist vaccine development studies. In addition, if the microorganism can be cultured, many analyses permitted by living microorganisms can be performed and antimicrobial activities that will guide therapeutic applications can be tested (Grózner et al., 2016). Cultural and serological methods are mostly used for the diagnosis and identification of Mycoplasma species. However, the use of these methods is limited by the fact that they are fragile microorganisms when it comes to reproduction in artificial environments, their cultures are time-consuming, their species cannot be distinguished easily due to their close microbiological characteristics, in addition, there is a lack of qualified antisera to be used in serological tests in routine experiments and they show low diagnostic sensitivity. Moreover, these methods are inadequate in the differentiation of the aforementioned co-infection and mixed infections (Kilıç et al., 2010; Umar et al., 2016). Nucleic acidbased molecular methods are widely used for more precise and practical identification at the species level and can even reveal new species and variants and their taxonomic positioning (Grózner et al., 2019a, b). In addition, molecular methods can scan asymptomatic or porter animals by directly detecting the microorganism from clinical samples. In this context, conventional and real-time PCR techniques and probes that provide in vitro enzymatic amplification of bacterium-specific conserved gene regions such as $m g c 2, v / h A$, dnaX, rpo $B$, pcrA, 16S rRNA, and sequencing methods that perform the sequence analysis of nucleic acid belonging to certain microorganisms have been widely used in recent years (Ferguson-Noel et al., 2012; Fraga et al., 2013; Grózner et al., 2019a, b).

The study aimed to investigate Mycoplasma species in geese with pneumonia via lung samples taken during their slaughtering in Kars (Turkey), where traditional geese breeding is a wide-held practice, via cultural and molecular methods.

\section{MATERIALS AND METHODS}

\section{Study material}

Permission from the ethics committee for this study was obtained from the Kafkas University Local Ethical Committee of Animal Experiments (KAÜ-HADYEK) via Decision No. "2018-20".

As part of the study, a total of 500 pneumonic lung samples from geese living on 12 different farms in the Kars region and slaughtered in a slaughterhouse between 2019 and 2020 were examined for the presence of Mycoplasma species. All pneumonic lung samples were taken per asepsis and antisepsis rules and delivered to the laboratory without disrupting the cold chain. To be used in all analyses, reference strains such as $M$. anatis (NCTC 10156), $M$. anseris (ATCC 49234), M. cloacale (NCTC 10199) and $M$. anserisalpingitis (ATCC BAA-2147) were obtained from Dr. Miklos Gyuranecz (the Institute for Veterinary Medical Research, Center for Agricultural Research, Hungarian Academy of Sciences) and M. gallisepticum S6 and M. synovia 1853 strains were obtained from the culture collection of the Pendik Veterinary Control Institute (Turkey). 
Celebi Ö, Özdemir Ü, Büyük F, Ünsal Baca A, Erpek ŞH, Karahan M, Otlu S, Şahin M, Coşkun MR, Çelik E, Gülmez Sağlam A, Büyük E, Akça D
Isolation of Mycoplasma spp. from Geese with Pneumonia and Identification of Microbial Isolates via Molecular Methods

\section{Cultural analysis}

Tissue homogenate was prepared from samples of pneumonic lungs from geese in accordance with the protocol (Öztürkler \& Otlu, 2020). The homogenate was inoculated (10\% rate) on; a) Frey's broth (Fluka-F6797) supplemented with $20 \mathrm{ml}$ horse serum (Sigma-H1138), $1 \mathrm{ml} 1 \% \mathrm{NAD}, 1 \mathrm{ml} 1 \%$ cysteine, $1 \mathrm{ml}$ penicillin (20000

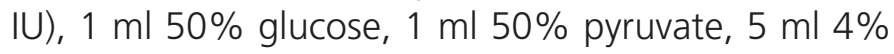
cresol red and b) Frey's agar (Fluka-F6797) plates supplemented with $20 \mathrm{ml}$ horse serum (Sigma-H1138), $1 \mathrm{ml} 1 \% \mathrm{NAD}, 1 \mathrm{ml} 1 \%$ cysteine, $1 \mathrm{ml}$ penicillin (20000 IU) and $1.5 \mathrm{~g}$ agar bacteriological. The plated media were incubated at $37^{\circ} \mathrm{C}$ for $4-7$ days in a humid environment with $5 \% \mathrm{CO}_{2}$. During the incubation period, a colour change due to the $\mathrm{pH}$ indicator was observed in Frey's broth and in positive cases, $10 \mu \mathrm{l}$ of the medium was inoculated onto Frey's agar plates and left to incubate under the same conditions. At the end of this period, pure cultures of the colonies with suspected mycoplasma were subcultured 3 times onto the Frey's agar media, which were examined with $35 x$ magnification under a stereomicroscope. A digitonin test was performed to distinguish Mycoplasma spp. isolates from Acholeplasma and a urease test to distinguish them from Ureaplasma species. The isolates were distinguished from L-forms by passaging them into non-inhibitor media (Tully, 1983). Species identification of the isolates confirmed as Mycoplasma spp. was performed via the Growth Inhibition Test (GIT) in the presence of the reference hyperimmune serums ( $M$. anatis, $M$. anseris, $M$. cloacale hyperimmune sera obtained from the Pendik Veterinary Control Institute, Turkey) (OIE, 2008).

\section{Molecular analysis}

\section{DNA extraction}

DNA extraction from pure Mycoplasma cultures and reference strains was carried out via the boiling method (Barbosa et al., 2016). For this purpose, $1 \mathrm{ml}$ of fresh liquid culture of the bacterium was taken and centrifuged at $14.000 \mathrm{rpm}$ for 30 minutes. $25 \mu \mathrm{l}$ of Sterile PCR grade water was added to the sediment obtained after centrifugation. The tubes were boiled in a hot water bath for 10 minutes, and then kept on the ice mould for 10 minutes. Samples kept in the oven at $37{ }^{\circ} \mathrm{C}$ until they were completely dissolved were then centrifuged at $14.000 \mathrm{rpm}$ for 5 minutes, and the supernatant containing DNA was collected and stored at $-20{ }^{\circ} \mathrm{C}$ until it was used in the PCR analysis. DNA needed for the Real-Time PCR analysis was extracted from the lung samples using a commercial kit (DNeasy Blood \& Tissue Kits, Qiagen) and as per the manufacturer's instructions.

\section{Species-specific PCR}

Species-specific PCR methods and primers that provide amplification of $d n a X, p c r A, r p o B$ gene regions were used for identifying the species of the Mycoplasma isolates (Grózner et al., 2019b).A PCR reaction was prepared uniformly for each Mycoplasma species and the reaction volume was set as $25 \mu \mathrm{l}$ consisting of $2 \mu \mathrm{l}$ template DNA, $2.5 \mu \mathrm{l}$ 10XPCR buffer (Qiagen, HotStarTaq DNA Polymerase, Germany), $2 \mu \mathrm{l}$ $\mathrm{MgCl}_{2}(25 \mathrm{mM}), 0.5 \mu \mathrm{ldNTP} \operatorname{mix}(10 \mathrm{mM}), 2 \mu \mathrm{l}$ primer F, $2 \mu \mathrm{l}$ primer $\mathrm{R}(10 \mathrm{pmol} / \mu \mathrm{l}), 0.125 \mu \mathrm{l}$ HotStarTaq DNA polymerase $(5 \mathrm{U} / \mu \mathrm{l})$, and the remaining volume was made up of nuclease free water. The PCR was carried out with a common thermal cycle consisting of initial denaturation at $95^{\circ} \mathrm{C}$ for $5 \mathrm{~min}$, followed by 40 cycles of denaturation at $95^{\circ} \mathrm{C}$ for $1 \mathrm{~min}$, binding for 1 min at $61^{\circ} \mathrm{C}$ and an extension for $1 \mathrm{~min}$ at $72^{\circ} \mathrm{C}$. The reaction was finalized with a final elongation stage at $72{ }^{\circ} \mathrm{C}$ for 5 minutes. Amplified products were stained with Xpert Green DNA dye (Grisp, Portugal) and run in a $1 \%$ agarose gel electrophoresis system and viewed under UV. Ultrapure water was used as a negative control matrix to monitor cross contamination. The amplification quality of the extracted Mycoplasma DNA was tested using species-specific PCR primers and certain amplicons were evaluated.

\section{Real-Time PCR}

The direct analysis of $M$. gallisepticum and $M$. synoviae on pneumonic lung samples obtained from geese was performed via the IDEXX RealPCR MG/ MS Multiplex Real-time PCR. The Real-time PCR mix for each sample in $35 \mu \mathrm{l}$ volume was set with a $20 \mu \mathrm{l}$ reaction mix (10 $\mu \mathrm{l} M$. gallisepticum/M. synoviae DNA mix and $10 \mu$ l DNA master mix), $5 \mu$ l negative control, 5 $\mu l$ positive control and $5 \mu$ I DNA. The Real-time PCR was performed on the LightCycler 96 (Roche, Switzerland) device. The Real-time PCR protocol was carried out with pre-denaturation at $95{ }^{\circ} \mathrm{C}$ for 1 minute, 45 cycles consisting of denaturation at $95{ }^{\circ} \mathrm{C}$ for 15 seconds and amplification at $60^{\circ} \mathrm{C}$ for 30 seconds. FAM for $M$. gallisepticum and CY-5 for $M$. synoviae were selected as reporter dyes. HEX-labeled internal control (IC) was used, which provides sample-borne inhibition control and kit reagent control. Samples that produced an amplification curve and had a threshold $(\mathrm{Cq})$ value of $>38$ were considered positive. 
Celebi Ö, Özdemir Ü, Büyük F, Ünsal Baca A, Erpek ŞH, Karahan M, Otlu S, Şahin M, Coşkun MR, Çelik E, Gülmez Sağlam A, Büyük E, Akça D
Isolation of Mycoplasma spp. from Geese with Pneumonia and Identification of Microbial Isolates via Molecular Methods

\section{Genus-specific PCR and Sequencing}

The sequence analysis of the Mycoplasma strains was performed at the Pendik Veterinary Control Institute of the Ministry of Agriculture and Forestry of the Republic of Turkey. The 16S rRNA gene region amplified by Mycoplasma genus-specific PCR was used for the sequence analysis. The PCR analysis of this region was performed in the presence of primers GPO3 (5'-GGGAGCAAACAGGATTAGATACCCT-3') and MGSO (5'-TGCACCATCTGTCACTCTGTTAACCTC-3'), which provides 280 bp amplicon (Van Kuppeveld et al., 1992). A PCR reaction with a total volume of $25 \mu \mathrm{l}$ for each sample was consisted of $2.5 \mu \mathrm{L} 10 x P C R$ buffer, $0.5 \mu \mathrm{L}$ dNTP mix (10 mM), $3 \mu \mathrm{L} \mathrm{MgCl} 2(25 \mathrm{mM}), 1 \mu \mathrm{L}$ primer $\mathrm{F}(10 \mathrm{pmol}), 1 \mu \mathrm{L}$ primer $\mathrm{R}(10 \mathrm{pmol}), 0.125 \mu \mathrm{l}$ Taq DNA polymerase $(5 \mathrm{U} / \mu \mathrm{l}), 3 \mu \mathrm{l}$ template DNA and $13.875 \mu \mathrm{l}$ nuclease-free water. The thermal cycle was created from initial denaturation at $94{ }^{\circ} \mathrm{C}$ for $5 \mathrm{~min}$, 35 cycles consisting of denaturation at $94{ }^{\circ} \mathrm{C}$ for 30 $\mathrm{sec}$, primer binding at $58{ }^{\circ} \mathrm{C}$ for $30 \mathrm{sec}$, elongation at $72{ }^{\circ} \mathrm{C}$ for $30 \mathrm{sec}$. The reaction was finalized with the last elongation step at $72{ }^{\circ} \mathrm{C} 5 \mathrm{sec}$. The analysis of PCR products was performed via electrophoresis with $2 \%$ agar gel. The final PCR products obtained were purified with an agarose gel DNA extraction kit (Roche). The sequence analysis of the purified PCR products was performed at the Genetics Laboratory of the Istanbul Pendik Veterinary Control Institute using the Big Dye Terminator v3.1 Cycle sequencing kit (Applied Biosystem) and ABI 3130XL DNA Analyzer. The obtained chromatogram and nucleotide sequence were analyzed by the BioEdit and Chromas programs. After the comparative analysis of the sequences via the web-based BLAST program, species identification was performed.

\section{Phylogenetic analysis}

The 16S rRNA gene sequences of the avian Mycoplasma type strains were downloaded from the Genbank in NCBI and aligned using CLUSTAL_W in MEGA version X (Hall, 2013). Also, Mycoplasma sp. strain 2045, which is the closest strain according to Genbank, was added to the phylogenetic analysis. Phylogenetic trees were constructed using neighbourjoining (NJ) (Saitou \& Nei, 1987). The evolutionary distance model of Kimura's two-parameter (Nishimaki \& Sato, 2019) was used to generate evolutionary distance matrices for NJ algorithms with 95\% partial deletion. For NJ, the rate variation among sites was modelled using the gamma distribution. The confidence values of the nodes were evaluated by bootstrap analysis based on 1000 re-samplings (Felsenstein, 1985; Saticioglu et al., 2021a, b).

\section{Statistical analysis}

The results of the agent isolation, molecular identification, and sequence analysis of the lungs of geese with pneumonia were presented, and the interpretation of these values was recorded as a percentage.

\section{RESULTS}

\section{Phenotypic analysis findings}

In this study, Mycoplasma growth was detected in $51(10.2 \%)$ of the 500 pneumonic lung samples collected from geese on 12 different farms in the Kars region of Turkey as a result of the cultural analysis on Frey's media. All isolates were differentiated from Acheloplasmas, Ureaplasma and L-forms, thus defined as Mycoplasma spp.

As a result of the GIT, 32 (62.75\%) of 51 Mycoplasma spp. were identified as $M$. anatis, $9(17.65 \%)$ as $M$. anseris and $5(9.8 \%)$ as $M$. cloacale. Five (9.8\%) isolates could not be identified at the species level using the aforementioned test method (Table 1).

\section{Molecular analysis findings}

\section{Species-specific PCR findings}

Molecular confirmation of the phenotypically identified Mycoplasma species was performed by species-specific PCR that amplified the dnaX, pcrA, rpo $B$ gene regions, and the identification of $32 M$. anatis, 9 $M$. anseris and $5 \mathrm{M}$. cloacale species was confirmed by the PCR (Figure 1). Three (5.88\%) of the 5 isolates that were defined as Mycoplasma spp. via phenotypic methods but could not be identified at the species level were later identified as $M$. anserisalpingitis by speciesspecific PCR. The two remaining isolates could not be identified by species-specific PCR (Table 1).

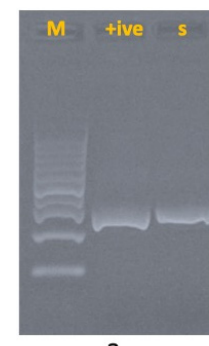

a

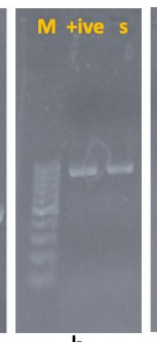

b

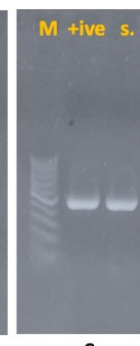

C

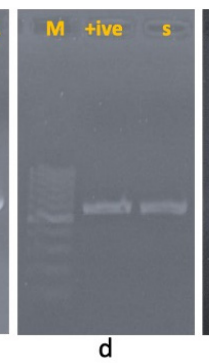

d

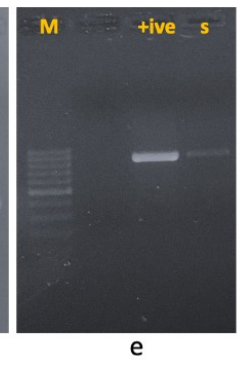

e
Figure 1 - Gel electrophoresis image of the PCR products representing the certain Mycoplasma species. PCR products of genus-specific PCR (a), M. anatis (b), M. anseris (c), M. cloacale (d), M. anserisalpingitis (e) species-specific PCR with 280 bp, 895 bp, 504 bp, 591 bp, 857 bp, respectively. M: marker, +ive: positive control (M. anatis NCTC10156 for ' $a$ ' and 'b', M. anseris ATCC 49234 for ' $c$ ', M. cloacale NCTC10199 for ' $d$ ', M. anserisalpingitis ATCC BAA-2147 for ' $e$ '), s: field isolate. 
Celebi Ö, Özdemir Ü, Büyük F, Û̉nsal Baca A, Erpek ŞH, Karahan M, Otlu S, Şahin M, Coşkun MR, Çelik E, Gülmez Sağlam A, Büyük E, Akça D
Isolation of Mycoplasma spp. from Geese with Pneumonia and Identification of Microbial Isolates via Molecular Methods

Table 1 - Mycoplasma species and their identification properties.

\begin{tabular}{|c|c|c|c|c|c|c|c|c|}
\hline \multirow[b]{2}{*}{ Mycoplasma Species } & \multirow{2}{*}{$\begin{array}{l}\text { Growth } \\
\text { Inhibition } \\
\text { Test }\end{array}$} & \multirow{2}{*}{$\begin{array}{l}\text { Species- } \\
\text { Specific } \\
\text { PCR }\end{array}$} & \multirow{2}{*}{$\begin{array}{l}\text { Sequence } \\
\text { Analysis }\end{array}$} & \multicolumn{4}{|c|}{ NCBI Data } & \multirow{2}{*}{$\begin{array}{l}\text { Direct Analysis of } \\
\text { the Tissue with } \\
\text { Real-Time PCR }\end{array}$} \\
\hline & & & & Strain Name & Accession Number & Identity Score (\%) & $\begin{array}{l}\text { ACNO of Bacterium } \\
\text { Genealogized }\end{array}$ & \\
\hline M. anatis & 32 & 32 & N/A & N/A & $\mathrm{N} / \mathrm{A}$ & $\mathrm{N} / \mathrm{A}$ & $N / A$ & $\mathrm{~N} / \mathrm{A}$ \\
\hline M. anseris & 9 & 9 & $\mathrm{~N} / \mathrm{A}$ & $\mathrm{N} / \mathrm{A}$ & $\mathrm{N} / \mathrm{A}$ & $\mathrm{N} / \mathrm{A}$ & $\mathrm{N} / \mathrm{A}$ & $\mathrm{N} / \mathrm{A}$ \\
\hline M. cloacale & 5 & 5 & $\mathrm{~N} / \mathrm{A}$ & $\mathrm{N} / \mathrm{A}$ & $\mathrm{N} / \mathrm{A}$ & $\mathrm{N} / \mathrm{A}$ & $\mathrm{N} / \mathrm{A}$ & $\mathrm{N} / \mathrm{A}$ \\
\hline M. anserisalpingitis & - & 3 & N/A & $\mathrm{N} / \mathrm{A}$ & $\mathrm{N} / \mathrm{A}$ & $\mathrm{N} / \mathrm{A}$ & $\mathrm{N} / \mathrm{A}$ & $\mathrm{N} / \mathrm{A}$ \\
\hline Mycoplasma sp. 2045 & - & N/A & 2 & $\begin{array}{l}\text { M4 } \\
\text { M48 }\end{array}$ & $\begin{array}{l}\text { MW858371 } \\
\text { MW858373 }\end{array}$ & $\begin{array}{l}98.17 \\
97.80\end{array}$ & MK615061.1 & N/A \\
\hline M. gallisepticum & N/A & $\mathrm{N} / \mathrm{A}$ & $\mathrm{N} / \mathrm{A}$ & $\mathrm{N} / \mathrm{A}$ & N/A & N/A & N/A & 3 \\
\hline $\begin{array}{l}\text { M. gallisepticum and } \\
\text { M. synoviae }\end{array}$ & N/A & N/A & N/A & N/A & N/A & N/A & N/A & 1 \\
\hline
\end{tabular}

N/A: not applicable ACNO: accession number

\section{Real-Time PCR findings}

The direct analysis of other Mycoplasma species, $M$. gallisepticum and $M$. synoviae, from pneumonic lung tissue samples was performed via the Real-time PCR. $M$. galliseptium in 3 samples and $M$. gallisepticum/ $M$. synoviae in 1 sample came up positive in the samples (Table 1).

\section{Genus specific PCR/Sequence/Phylogenetic analysis findings}

Genus-specific PCR followed by sequencing was applied to the 2 isolates that could not be identified via GIT and species-specific PCR. The 16S rRNA gene sequences of the isolates M4 and M48 (275 bp and $276 \mathrm{bp}$ in length, respectively) were obtained and subjected to comparative analysis. The 16S rRNA gene sequence similarity of the strain M4 was found 95.60\% with the Mycoplasma cynos strain H831. The $16 \mathrm{~S}$ rRNA gene sequence identity level between the strains M4 and M48 was $99.64 \%$. Two isolates were grouped in the same branch and the nearest neighbour was Mycoplasma sp. 2045 (MK615061.1) (Spergser, 2008) (Figure 2).

\section{DISCUSSION}

The tempting properties of food products in terms of consumption and their preference as a filler in textiles carry the geese farming sector to the forefront of poultry breeding in many countries. In Turkey, geese farming is generally grown to meet the food needs of the local population and has just begun to gain importance as a luxury food for a wide scope of consumers (Arslan, 2013). While the Mycoplasma species cause significant economic losses by causing pneumonia, arthritis, osteodystrophy, genital system infections and immunosuppression in geese with their horizontal and privileged vertical transmissions, the most important of these are their destructive effects on the respiratory system (Nascimento et al., 2005; Dobos-Kovács et al., 2009; Stipkovits \& Szathmary, 2012; Otlu, 2016). In this study, Mycoplasma species were detected in $11 \%$ (55/500) of pneumonic lung samples obtained from geese. A direct proportional comparison could not be made since there are no similar studies on the prevalence of $M$. anatis, $M$. anseris, $M$. cloacale and $M$. anserisalpingitis in cases of geese with pneumonia. Most of these studies are case reports or sequence and taxonomic analyses of a collection of strains obtained from different periods or locations (Grózner et al., 2019a, b). Nevertheless, although the prevalence of $M$. gallisepticum and M. synoviae is low, other Mycoplasma species and their prevalence are similar to those described in the aetiology of pneumonia in geese (Benčina et al., 1987; Stipkovits et al., 1987; Ivanics et al., 1988; Stipkovits \& Kempf, 1996; Ferguson-Noel et al., 2012; Stipkovits \& Szathmary, 2012; Grózner et al., 2016).

M. gallisepticum and $M$. synoviae are the causative agents of Chronic Respiratory Disease (CRD) and Infectious Synovitis (IS), respectively, and cause infections mainly in chickens and turkeys. Lower egg yield and quality are more prominent in $M$. synoviae infections. The frequency of asymptomatic infections can reach $90 \%$. Other bird species may also be affected by these microorganisms, but there are no clear clinical findings (Mohammed et al., 1985; Lutrell et al., 1996). In studies conducted in our country, M. gallisepticum and M. synoviae positivity was detected in $0.7 \%-20.9 \%$ of poultry (Ülgen, 1991; Güler, 1992). In this study, frequency of $M$. gallisepticum and $M$. synoviae was lower than in other studies (Ülgen, 1991; Güler, 1992) with $0.008 \%$ and $0.002 \%$, respectively, and even they could not be cultured in a similar way (Dakman et al., 2009). However, even if they were detected via direct $P C R$, the presence of a $M$. gallisepticum and $M$. synoviae 
Çelebi Ö, Özdemir Ü, Büyük F, Ünsal Baca A, Erpek ŞH, Karahan M, Otlu S, Şahin M, Coşsun MR, Çelik E, Gülmez Sağlam A, Büyük E, Akça D
Isolation of Mycoplasma spp. from Geese with Pneumonia and Identification of Microbial Isolates via Molecular Methods

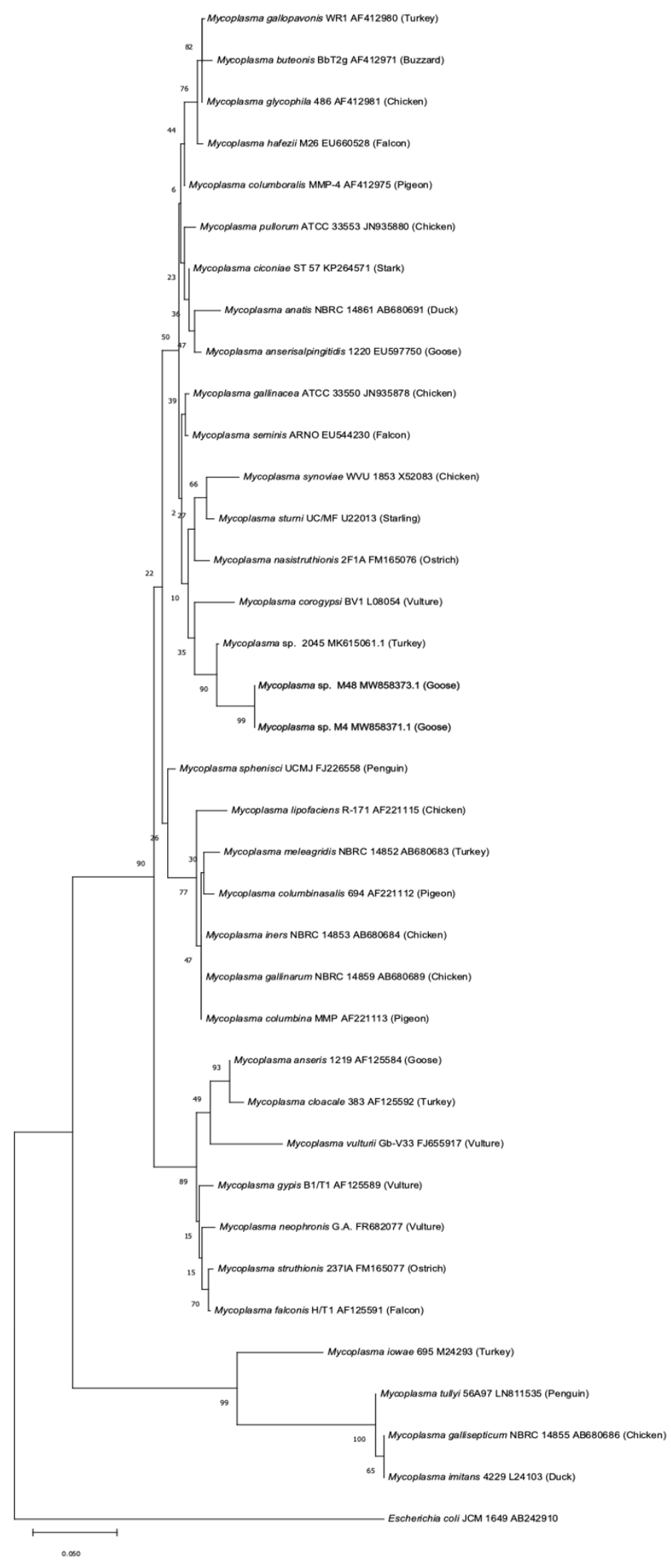

Figure 2 - The neighbour-joining phylogenetic tree constructed from 16S rRNA gene sequences showing the phylogenetic position of the strains M4 and M48 among avian Mycoplasma species. The numbers on the branch nodes represent the percentages of 1000 bootstrap replicates. GenBank accession numbers for the 165 rRNA gene sequences are shown after the strain name. Escherichia coli JCM 1649'was used as an outgroup. mixed infection was similar to what was previously reported (Bagal et al., 2019). The positivity rates of $M$. gallisepticum and $M$. synoviae, which are known as the predominant species of respiratory system infections in poultry species such as chickens and turkeys, were found to be lower in geese in this study as expected, contrary to those previously reported (Ülgen, 1991; Güler, 1992). This low positivity rate may be influenced by the host specificity of Mycoplasma species, as well as the lower prevalence of CRD and IS infections, which are more infectious in restricted chicken and turkey populations and observed as local epidemics. This low positivity rate is an expected situation in such collection materials which were randomly generated from goose lung samples obtained from different farms during slaughtering.

$M$. anatis together with the other Mycoplasma species ( $M$. anseris, $M$. cloacale, $M$. anserisalpingitis) was identified in the respiratory system, genital system and nervous system infections, and usually as coinfections in ducks. The pathology and roles of $M$. anatis in respiratory system infections (lymphohistiocytic infiltration in the lungs), of which colonization is more limited in geese, is little known (Ivanics et al., 1988). In this study, the prevalence of $M$. anatis in the lungs of pneumonic geese was determined to be $6.4 \%$ $(32 / 500)$ and it was the most common species among the Mycoplasma species with a rate of $58.18 \%$. Considering the presence of $M$. anatis in tissues such as the oropharynx, trachea, cloaca, and oviduct in healthy geese (Benčina et al., 1987; Grózner et al., 2019b), it encourages us to persue further study to elucidate the role of this highly prevalent bacterium in the pathology of pneumonia. In addition, the prevalence of this Mycoplasma species, which is usually isolated from ducks, in cases of pneumonia in geese can be considered a result of the mixed breeding of these geese with ducks in the area of the study.

$M$. anseris, which was first isolated from the phallus lymph node of a male goose in Hungary (Bradbury et al., 1988), gradually increased the prevalence of similar infections in geese in the following years, while cases of cloaca inflammation and airsacculitis, peritonitis and embryonal deaths have also been reported (Stipkovits \& Kempf, 1996; Stipkovits \& Szathmary, 2012). Unlike other pneumonic bacteria, $M$. anseris has a much less significant role in respiratory system infections. It is known that the disease incidence varies depending on herd structure and density, as well as farm hygiene. Obvious clinical symptoms (nasal discharge, coughing, dyspnea and low mortality) and pathological lesions 
Celebi Ö, Özdemir Ü, Büyük F, Ünsal Baca A, Erpek ŞH, Karahan M, Otlu S, Şahin M, Coşkun MR, Çelik E, Gülmez Sağlam A, Büyük E, Akça D
Isolation of Mycoplasma spp. from Geese with Pneumonia and Identification of Microbial Isolates via Molecular Methods (pneumonia, airsacculitis and peritonitis) are limited in respiratory system infections that occur following practices such as keeping geese in a closed environment for a long time and forced feeding (Stipkovits \& Kempf, 1996). In this study, the prevalence of $M$. anseris in the sampled lungs was found to be 1.8\% (9/500) and ranked second among the Mycoplasma species defined with a rate of $16.36 \%$. The high incidence of $M$. anseris, whose presence in clinical samples is interpreted as absolute infection (Stipkovits \& Kempf, 1996; Stipkovits \& Szathmary, 2012), as was the case in this study, and especially its culturability from inflamed lungs, further strengthen its place as a causative agent of pneumonia.

M. cloacale, which is not as host specific as other Mycoplasma species (Braburry et al., 1988), has been reported in geese both in infertility cases (Stipkovits \& Kempf, 1996) and in healthy animals (Benčina et al., 1987; Hinz et al., 1994). The presence of $M$. cloacale in geese is generally seen along with $M$. anseris and $M$. anserisalpingitis as a co-occurrence or co-infection (Hinz et al., 1994). However, M. cloacale has not been associated with lung infections. In this study, the prevalence of $M$. cloacale in pneumonic geese was found to be 1\% (5/500) and 9.09\% among the Mycoplasma species identified. Additional studies are needed to explain the role of $M$. cloacale in the pathology of pneumonia, as within other Mycoplasma species.

M. anserisalpingitis leads to serious economic loss by causing inflammation in the cloaca and phallus, salpingitis, a decrease in egg production and embryonal death in geese (Stipkovits et al., 1986; Dobos-Kovács et al., 2009). The bacterium has also been reported in the liver, ovaries, testes and peritoneum (Volokhov et al., 2020). Apart from this, M. anserisalpingitis has also been detected in respiratory system infections such as airsacculitis, and in the trachea and as lung inflammation in waterfowl such as geese and ducks (Stipkovits et al., 1987; Grózner et al., 2016). In this study, the prevalence of $M$. anserisalpingitis in pneumonic lungs was determined to be $0.6 \%(3 / 500)$ and $5.45 \%$ among the Mycoplasma species identified. A proportional comparison could not be made due to limited reporting on cases of pneumonia caused by $M$. anserisalpingitis in geese.

Literary data on Mycoplasma sp. 2045 is currently only one. It consisted of the information obtained from a turkey's choana sample in Austria in 2008 and contained the partial sequence analysis of the $16 \mathrm{~S}$ rRNA gene in the NCBI database (accession number
MK615061.1) (Spergser, 2008). In this study, two Mycoplasma strains, which could not be identified by GIT and PCR but were found identical to the Mycoplasma sp. 2045 strain (MK615061.1) as having $98.17 \%$ and $97.8 \%$ nucleotide similarity after the partial sequence analysis of the 16S rRNA gene region. Hence, as shown by their 16S rRNA gene sequence identity levels below the threshold of $98.7 \%$ for species demarcation with all other Mycoplasma species, both isolates were identified as Mycoplasma spp., a fact also confirmed by their phylogenetic trees (Figure 2). However, differences observed in the GPO-3/MGSO amplicons should not be overestimated since the genus-specific primers yield a small fraction of the $16 \mathrm{~S}$ rRNA gene when compared to the whole 16S rRNA gene. For now, these isolates have been genealogized to the relevant strain in line with their similarity scores obtained from the BLAST analysis, thus polyphasic studies consisting of genotypic (especially a full-length $16 \mathrm{~S}$ rRNA sequence of type strain), chemotaxonomic, and phenotypic methods are advised (Chun et al., 2018) to introduce them into the taxonomy and give them a taxonomic position as a novel Mycoplasma strain. In addition, due to a lack of reports, the prevalence and pathogenicity of these Mycoplasma species concerned are questionable. However, the absence of other dominant or recessive Mycoplasma species in the lung samples where this bacterium was isolated suggests the possibility of this bacterium being a pathogenic species. The possible predisposition of other bacteria (Pasteurella multocida, Avibacterium paragallinarum and Ornithobacterium rhinotracheale) and viruses (Infectious Bronchitis Virus and Newcastle Disease Virus) in the respiratory tract (Van et al., 2020) also strengthens this possibility. Nevertheless, conducting host or host-independent pathogenicity tests would provide valuable data to clarify these concerns.

In conclusion, the prevalence of Mycoplasma species identified in cases of pneumonia in geese was found to be significantly high (11\%). It is seen that the species dominance in the aetiology of pneumonia of Mycoplasma species, which share similar chances in terms of their in vitro culturing, may vary from time to time. Considering the existence of these Mycoplasma species in classical respiratory system infections and their economic damages as well as their prevalence in embryonal deaths, phallus and cloaca infections and their vertical transmission characteristics, these will also improve the importance of studies on these species in geese with low reproductive efficiency and fertility. It shows that species-specific PCR and the 16S rRNA gene 
Çelebi Ö, Özdemir Ü, Büyük F, Ünsal Baca A, Erpek ŞH, Karahan M, Otlu S, Şahin M, Coșkun MR, Çelik E, Gülmez Sağlam A, Büyük E, Akça D
Isolation of Mycoplasma spp. from Geese with Pneumonia and Identification of Microbial Isolates via Molecular Methods sequencing have sufficient specificity to identify these agents in the differentiation of Mycoplasma species that are morphologically and biochemically very close.

\section{ACKNOWLEDGMENTS}

This research was supported by the Research Fund of Kafkas University with a Project No: 2018-TS-33. The authors would like to thank Prof Fuat Aydın and Dr. Izzet Burçin Satıcıoğlu from the Veterinary Faculty of Erciyes University (Turkey) for their help with the phylogenetic analysis editing.

\section{CONFLICT OF INTEREST}

The authors declare that they have no conflict of interest.

\section{REFERENCES}

Arslan C. Kaz Besleme ve Yetiştiriciliği. 2. Baskı. Malatya: Medipres Matbaaclık Yayıncılık; 2013. p.1-130.

Bagal U, Dhaygude V, Kamdi B, Mote C, Pawade M, Bhosale S. Pathology and molecular diagnosis of Mycoplasma gallisepticum and Mycoplasma synoviae infections in broiler chickens from western Maharashtra, India. Journal of Animal Research 2019;9:897-902.

Barbosa C, Nogueira S, Gadanho M, Chaves S. DNA extraction: finding the most suitable method. Molecular Microbial Diagnostic Methods 2016;135-154.

Bradbury JM, Jordan FTW, Shimizu T, Stipkovits L, Varga Z. Mycoplasma anseris sp. nov. found in geese. International Journal of Systematic Bacteriology1988;38:74-76.

Benčina D, Dorrer D, Tadina T. Mycoplasma species isolated from six avian species. Avian Pathology 1987;16:653-664.

Chun J, Oren A, Ventosa A, Christensen H, Arahal DR, da Costa MS, et al. Proposed minimal standards for the use of genome data for the taxonomy of prokaryotes. The International Journal of Systematic and Evolutionary Microbiology 2018;68:461-466.

Dakman A, Günaydın E, Türkyılmaz MA, Güleç M, Coşar M, Özdemir Ü. Mycoplasma infections detected in breeder holdings. Etlik Veteriner Mikrobiyoloji Dergisi 2009;20:27-34.

Dobos-Kovács M, Varga Z, Czifra G, Stipkovits L. Salpingitis in geese associated with Mycoplasma sp. strain 1220. Avian Pathology 2009;38:239-243.

FAO - The Food and Agriculture Organization. Goose production [paper 154]. Rome: FAO Animal Production and Health; 2002. p.69-83.

Felsenstein J. Confidence limits on phylogenies: a approach using the bootstrap. Evolution 1985;39:783-791.

Ferguson-Noel N, Victoria AL, Farrar M. Influence of swabmaterial on the detection of Mycoplasma gallisepticum and Mycoplasma synoviae by real-time PCR. Avian Diseases 2012;56:310-314.

Fraga AP, Vargas T de, Ikuta N, Fonseca AS, Celmer Ás. A multiplex realtime PCR for detection of Mycoplasma gallisepticum and Mycoplasma synoviae in clinical samples from Brazilian commercial poultry flocks. The Brazilian Journal of Microbiology 2013;44:505-510.
Grózner D, Kreizinger Z, Sulyok KM, Rónai Z, Hrivnák V, Turcsányiet I, et al. Antibiotic susceptibility profiles of Mycoplasma sp. 1220 strains isolated from geese in Hungary. BMC Veterinary Research 2016;12:170.

Grózner D, Forró B, Kovács ÁB, Marton S, Bányai K. Complete genome sequences of three Mycoplasma anserisalpingitis (Mycoplasma sp. 1220) strains. Microbiology Resource Announcements 2019a;8:e00985-19.

Grózner D, Sulyok KM, Kreizinger Z, Rónai Z, Jánosi S. Detection of Mycoplasma anatis, M. anseris, M. cloacale and Mycoplasma sp. 1220 in waterfowl using species-specific PCR assays. PLoS ONE 2019b;14:e0219071.

Gyuranecz M, Mitter A, Kovács ÁB, Grózner D, Kreizinger Z, Bali K, et al. Isolation of Mycoplasma anserisalpingitidis from swan goose (Anser cygnoides) in China. BMC Veterinary Research 2020;16:178.

Güler L. Konya bölgesindeki kümes hayvanlarında serolojik yoklamalarla müspet bulunan CRD vakalarından etken izolasyon çalışmaları. Konya (TR): Uzmanlık Tezi, Tarım ve Köyişleri Bakanlığı; 1992.

Hall BG. Building phylogenetic trees from molecular data with MEGA. Molecular Biology and Evolution 2013;30:1229-1235.

Hinz KH, Pfutzner $H$, Behr KP. Isolation of mycoplasmas from clinically healthy adult breeding geese in Germany. Zentralblatt Veterinarmedizin Reihe B1994;41:145-147.

Ivanics E, Glavits R, Takacs G, Molnar E, Bitay Z. An outbreak of Mycoplasma anatis infection associated with nervous symptoms in large-scale duck flocks. Journal of Veterinary Medicine 1988;35:368-378.

Kılıç A, Kalender H, Muz A. Mycoplasma infections in poultry. Journal of Veterinary Science 2010;5:92-102.

Lutrell MP, Fischer JR, Stallknecht DE, Kleven SH. Field investigation of Mycoplasma gallisepticum in house finches (Carpodacus mexicanus) from Maryland and Georgia. Avian Disease 1996;40:335-341.

Mohammed HO, Carpenter TE, Yamamoto R, McMartin DA. Prevalance of Mycoplasma gallisepticum and M. synoviae in commercial layers in Southern and Central California. Avian Disease 1985;30:519-526.

Nascimento ER, Pereira VLA, Nascimento MGF, Barreto ML. Avian mycoplasmosis update. Brazilian Journal of Poultry Science 2005;7:1-9.

Nishimaki T, Sato K. An extension of the Kimura two-parameter model to the natural evolutionary process. The Journal of Molecular Evolution 2019;87:60-67.

OIE - Office International des Epizooties. Contagious agalactia. In: OIE. Terrestrial manual. France; 2008. p.992-997.

Otlu S. Infectious diseases in geese. Turkiye Klinikleri Reproduction and Artificial Insemination- Special Topics 2016;2:56-65.

Öztürkler O, Otlu S. A phylogenetic analysis of Mycoplasma strains circulating in sheep pneumonia in the Kars region of Turkey. The Turkish Journal of Veterinary and Animal Sciences 2020;44:805-813.

Sá SG de, Pinheiro Júnior JW, Oliveira Vilela SM de, Moraes EPBX, Albuquerque PPF, Ferreira DRA. Occurrence and risk factors assessment associated with Mycoplasma gallisepticum (MG) infection in chickens in the semiarid region of Pernambuco, Brazil. Pesquisa Veterinária Brasileira 2015;35(6):531-535.

Saitou N, Nei M. The neighbor-joining method: A new method for reconstructing phylogenetic trees. Molecular Biology and Evolution 1987:4:406-425.

Samy A, Naguib MM. Avian respiratory coinfection and impact on avian influenza pathogenicity in domestic poultry: Field and experimental findings. Journal of Veterinary Science 2018;5(1):23. 
Celebi Ö, Özdemir Ü, Büyük F, Ünsal Baca A, Erpek ŞH, Karahan M, Otlu S, Şahin M, Coşkun MR, Çelik E, Gülmez Sağlam A, Büyük E, Akça D
Isolation of Mycoplasma spp. from Geese with Pneumonia and Identification of Microbial Isolates via Molecular Methods
Saticioglu IB, Ay H, Duman M, Altun S, Sahin N. Flavobacterium bernardetii sp. nov., a possible emerging pathogen of farmed rainbow trout (Oncorhynchus mykiss) in cold water. Aquaculture 2021a;540:736717.

Saticioglu IB, Ay H, Altun S, Duman M, Sahin N. Flavobacterium turcicum sp. nov. and Flavobacterium kayseriense sp. nov. isolated from farmed rainbow trout in Turkey. Systematic and Applied Microbiology $2021 b ; 44: 126186$.

Spergser J. Mycoplasma sp. strain 2045 16S ribosomal RNA gene, partial sequence. Vienna: Department of Pathobiology, Institute of Microbiology, Veterinaerplatz; 2008. [cited 2021 Feb 01]. Available from: https://www.ncbi.nlm.nih.gov/nuccore/MK615061.1/. 2008.

Stipkovits L, Varga Z, Czifrag Y, Dobos-Kovacs M. Occurrence of mycoplasmas in geese affected with inflammation of the cloaca and phallus. Avian Pathology 1986;15:289-299.

Stipkovits L, Varga Z, Glavits R, Ratz F, Molnar E. Pathological and immunological studies on goose embryos and oneday-old goslings experimentally infected with a mycoplasma strain of goose origin. Avian Pathology 1987;16:453-468.

Stipkovits L, Kempf I. Mycoplasmoses in poultry. Revue Scientifique et Technique (International Office of Epizootics) 1996;15:1495-1525.

Stipkovits L, Szathmary S. Mycoplasma infection of ducks and geese. Poultry Science 2012;91:2812-2819.

Tiong SK. Mycoplasmas and Acholeplasmas isolated from ducks and their possible association with pasteurellas. Veterinary Record 1990;127:6466.
Tully JG. Tests for digitonin sensitivity and sterol requirement. In: Tully JG Razin S, editors. Methods in mycoplasmology I. New York: Academic Press, 1983. p.355-362.

Umar S, Munir MT, Ur-Rehman Z, Subhan S, Azam T. Mycoplasmosis in poultry: update on diagnosis and preventive measures. Worlds Poultry Science Journal 2016;73:17-28.

Ülgen M. Kanatlıların kronik solunum yolu enfeksiyonu üzerinde karşılaştırılmalı bakteriyolojik ve serolojik araştırmalar [doktora tezi]. Bursa (TUR): Uludağ Üniversitesi, Sağlık Bilimleri Enstitüsü; 1991.

Van NTB, Yen NTP, Nhung NT, Cuong NV, Kiet BT, Van Hoang N, et al. Characterization of viral, bacterial, and parasitic causes of disease in small-scale chicken flocks in the Mekong Delta of Vietnam. Poultry Science 2020;99:783-790.

Van Kuppeveld FJM, Van der Logt JTM, Angulo AF, VanZoest MJ, Quint WGV, Niesters HGM, et al. Genus- and species-specific identification of mycoplasmas by $16 \mathrm{~S}$ rRNA amplification. Applied and Environmental Microbiology 1992;58:2606-2615.

Volokhov DV, Grózner D, Gyuranecz M, Ferguson-Noel N, Gao Y, Bradbury $\mathrm{JM}$, et al. Mycoplasma anserisalpingitidis sp. nov., isolated from European domestic geese (Anser anser domesticus) with reproductive pathology. The International Journal of Systematic and Evolutionary Microbiology 2020;70:2369-2381. 
